\title{
The Effects of Reverse Knowledge Spillover on China's Sustainable Development: Sustainable Development Indicators Based on Institutional Quality
}

\author{
Xiaoxu Dong ${ }^{1}\left(\mathbb{D}\right.$, Cheon $\mathrm{Yu}^{2}$ and Yun Seop Hwang ${ }^{3, *}$ \\ 1 School of Business, Shandong University of Political Science and Law, Jinan 250014, China; \\ dong.xiaoxu.1988@163.com \\ 2 Department of International Trade, Mokpo National University, Jeonnam 58544, Korea; yu1000@mokpo.ac.kr \\ 3 International Business \& Trade, Kyung Hee University, Seoul 130-701, Korea \\ * Correspondence: rusiahys@khu.ac.kr
}

Citation: Dong, X.; Yu, C.;

Hwang, Y.S. The Effects of Reverse Knowledge Spillover on China's Sustainable Development: Sustainable Development Indicators Based on Institutional Quality.

Sustainability 2021, 13, 1628.

https://doi.org/10.3390/su13041628

Academic Editor: Bruce Morley

Received: 28 December 2020

Accepted: 24 January 2021

Published: 3 February 2021

Publisher's Note: MDPI stays neutral with regard to jurisdictional claims in published maps and institutional affiliations.

Copyright: (c) 2021 by the authors. Licensee MDPI, Basel, Switzerland. This article is an open access article distributed under the terms and conditions of the Creative Commons Attribution (CC BY) license (https:// creativecommons.org/licenses/by/ $4.0 /)$.

\begin{abstract}
This study investigates how reverse knowledge spillover (RKS) generated through outward foreign direct investment (OFDI) promotes sustainable development in an investment home country. Economic, social, and environmental dimensions are the pillars of sustainable development and their indicators are developed upon the concept of institutional quality. To this end, we use a balanced panel of 30 Chinese Mainland provinces from 2003 to 2016 and employ a simultaneous equation model to analyze the data in order to observe the direct and indirect effects of OFDI-induced RKS on sustainable development. The current study adopts several indicators to capture the economic, social, and environmental aspects of sustainable development. Additionally, we classify RKS into two types, given the investment destinations in terms of developed economies and emerging economies. On the one hand, our findings confirm that OFDI-induced RKS from developed economies facilitates domestic innovation but negatively affects progress on social and environmental development. On the other hand, OFDI-induced RKS from emerging economies is not conducive to domestic innovation, but it directly fosters sustainable development.
\end{abstract}

Keywords: outward foreign direct investment (OFDI); reverse knowledge spillover (RKS); innovation; sustainable development; institutional quality; China

\section{Introduction}

Sustainable development has become a universal goal for both developed and emerging economies since the United Nations endorsed the 2030 Agenda for Sustainable Development [1]. Sustainable development can be achieved if countries engage in developmental efforts to satisfy the needs of the present generation while not harming the needs of future generations [2]. Examples of sustainable development include the promotion of economic development, the enhancement of social welfare, and the protection of environmental ecology. Accomplishing sustainable development goals is innately associated with the institutional level and quality of a government. Both well-structured institutions and well-designed execution systems embody institutional quality, which is the conceptual foundation of sustainable development. Improvement of institutional quality enhances the innovation of a firm, which in turn helps it to acquire competitive advantage and thus to contribute to the sustainable development of a nation [3]. For this reason, measures and indicators of sustainable development have been developed on the basis of institutions.

It is not surprising that sustainable development is often considered a challenging goal, because sustainability and development are two opposing concepts [4]. Emerging economies with a relatively low level of economic development need rapid economic growth in the short term. However, rapid economic growth often requires the extraction of many natural resources without adequate protection, which is likely to damage the natural 
environment. In this regard, developed economies have demonstrated that an innovationcentered approach is an effective way to achieve sustainable development $[5,6]$. Previous studies show that innovation can promote economic growth, e.g., [7], mitigate societal problems, e.g., [8], and reduce environmental stress, e.g., [9], which together demonstrate the three dimensions of sustainable development [10].

Meanwhile, technological change and innovation pave the road to sustainable development [11,12]. Technological change and innovation depend on investment in research and development $(R \& D)$ by local government or enterprises, as well as on international diffusion and the spillover of knowledge and technology [13-15], which is known as an international knowledge spillover [16]. In the past few decades, trade and foreign direct investment (FDI) from developed economies have been considered the primary channels of international knowledge spillover to emerging economies [17,18]. Knowledge spillover (KS) from the investment destination country back to the investment home country is called reverse knowledge spillover (RKS) [19]. RKS indicates that emerging economies have the potential to promote innovation through the RKS effects of their outward FDI (OFDI), e.g., [20,21]. While previous literature has mainly attended to the economic effects of OFDI-induced RKS on the investment home country, it is not yet known how innovation brought by RKS can help emerging economies to achieve sustainable development.

The purpose of this research is to use the case of China to explore whether OFDIinduced RKS in developing countries promotes sustainable domestic development by influencing innovation performance. The second objective is to investigate the conditions under which OFDI-induced RKS affects the sustainable development of the investment home country. This study is also intended to reveal the policy implications for developing economies, which must achieve not only economic development, but also sustainability.

With regard to the source of OFDI-induced RKS, we consider that the heterogeneity of the investment host country will generate different effects of OFDI-induced RKS on sustainable development in the investment home country. For example, frontier innovation typically occurs in developed economies rather than emerging economies. Thus, we suspect that OFDI-induced RKS from developed and emerging economies will yield different impacts on sustainable development in China.

We chose China as an appropriate research setting to examine the relationship between OFDI-induced RKS and sustainable development, given that the country has been struggling to handle the dual task of boosting its national economy and promoting its ecological environment [22]. China's progress on sustainable development is a primary concern, not only for China but also for the rest of the world, because China exerts a significant influence on the world economy. China is one of the main engines of global economic growth. According to IMF statistics, from 2009 to 2018, China's contribution to global GDP growth was as high as 34\% (calculated at market exchange rates) or $27.7 \%$ (calculated at purchasing power parity), ranking it first in the world.

However, according to the 2018 ranking of SDG index, China only ranked 54th in 2018. This report was jointly released by UN Sustainable Development Solutions Network (UNSDSN) and the Bertelsmann Foundation. The "Evaluation Report on the Sustainable Development of China, 2018", a report that was jointly released by the China Center for International Economic Exchanges, the Earth Institute of Columbia University, and the Ali Research Institute, found that, while the economy was developing vigorously, some provinces and cities in China were facing severe environmental pressure. Indicators such as resources and environment, consumption and emissions, and environmental governance are relatively backward, which resulted in them ranking low in terms of sustainable development. In addition, some cities that were leading in terms of social conditions and people's livelihood are not in the top ten in terms of economic development. Economic development and people's livelihood and social conditions were not synchronized, indicating that some cities pay too much attention to economic development and neglect people's wellbeing. To some extent, this reflects the current imbalance and gaps in development of China. 
China's OFDI has grown dramatically since the implementation of the "Go Global" strategy in 2001. According to the 2017 Statistical Bulletin of China's OFDI, 37,200 foreigninvested enterprises were set up by 24,400 Chinese investors at the end of 2016 . These overseas enterprises are located in 190 countries (regions), and their total assets reached $\$ 5$ trillion. The impact of such overseas enterprises on the domestic development in China is vital for the future outward investment policies of China and other emerging economies.

The rest of the paper is organized as follows: Section 2 reviews the relevant literature, while Sections 3 and 4 describe the research methods and variable specification. Section 5 offers the empirical findings, and Section 6 concludes the paper along with limitations and suggestions for avenue for future research.

\section{Theoretical Background and Literature Review}

\subsection{Sustainable Development and Innovation}

Since the 1980s, sustainable development has become the new development agenda for a number of countries, and the concept of sustainable development has been understood as consisting of the three main pillars of economic, social, and environmental dimensions [23]. In this regard, the "triple bottom line" (TBL) was also introduced to indicate that sustainability can be achieved if there is a balance among economic prosperity, environmental quality, and social justice [24], which entail institutional norms [25]. In the TBL construct, every one of these three dimensions of sustainable development is indispensable. Economic sustainability refers to the necessary material and financial resources [26]. Social sustainability emphasizes social equality, a preservation of cultural diversity, and an improvement in human health and education levels. Environmental sustainability refers to maintaining the quality of the environment, which involves efficient utilization of energy resources, the reduction of greenhouse gas emissions, and the minimization of the ecological footprint [27].

There are two main schools of thought on the relationship between these three dimensions. One is the common three-ring sector view of sustainable development $[28,29]$. This view assumes a separation between the economy, society, and environment, which tends to underestimate the fundamental link between them. In this view, tradeoffs can be made between the three dimensions, and whichever dimension is the priority becomes the debate topic on sustainable development. Compared with the common three-ring view, the second view is nested sustainable development, which considers that the three dimensions of sustainable development are more integrated [25]. Putting the economy at the center does not mean it should be seen as the most important sector. Rather, it is a subset of the other two dimensions, and it depends on them [30,31]. Society embraces a variety of human activities, including the economy. Human activities occur within the environment, so almost all human activities will have an impact on the environment.

National governments and academics have begun to explore how to achieve sustainable development effectively to meet the needs of the present and to ensure the survival needs of future generations. How to balance the economic, social, and environmental is a difficult problem they must face. In theory, innovation is widely recognized as a critical driving force of sustainable development $[5,6,32,33]$.

First, the endogenous economic growth model presented by Romer $[34,35]$ and Lucas [36] emphasizes that the accumulation of knowledge is the main reason for economic growth and claims that endogenous technological progress is the decisive factor for sustained economic growth. Most empirical studies have taken developed economies as a research setting and found positive and significant relationships between innovation and economic growth $[37,38]$.

Second, social development is interconnected with economic growth, as social progress is hard to separate from the material basis brought by economic development $[25,28,29]$. For example, innovation led to the introduction of high-yield grain varieties and the increased efficient use of fertilizers and irrigation, which led to a substantial increase in grain production and mitigated the social development problem of food shortages [8]. 
The application of innovative technologies can also directly bring convenience to people and improve social well-being. For example, the advancement of medical equipment and technology and the popularization of water purification systems have all improved the quality of human life.

Third, technological change is an essential means to overcome or at least alleviate the shortage of environmental resources (e.g., [39]). In particular, environment-related innovation is considered an effective way to reduce the environmental burden [9,11,40,41]. Balsalobre Lorente and colleagues [42] found that government efforts in innovation and energy substitution helped reduce greenhouse gas emissions in 24 OECD countries from 1992 to 2010. This result reveals the importance of institutional quality in accomplishing sustainable development objectives. Fernández et al. [43] verified that innovation has a positive impact on the reduction in $\mathrm{CO}_{2}$ emissions of the $\mathrm{EU}$, the US, and China between 1990 and 2013. Additionally, the exploration of innovation and green growth has been increasing. Green growth means an emerging economy without damaging the environment, and it is a necessary condition and guarantee for sustainable development [44]. Several previous studies confirm that innovation is an essential factor in achieving green growth $[45,46]$. Given the aforementioned discussion, this paper argues that innovation has a positive impact on sustainable development in terms of economic, social, and environmental dimensions.

\subsection{OFDI-Induced Reverse Knowledge Spillovers}

Innovation improvement relies not only on domestic inputs but also on external factors through international KS. Since the 1990s, trade and FDI have generally been regarded as the main channels of international KS (e.g., [17,47]). Potterie and Lichtenberg [14] proposed that OFDI serves as a channel for international KS. This phenomenon is often referred to as RKS by scholars, indicating knowledge flow from the investment host country back to the investment home country [19,48-50]. Generally, emerging economies as the home country invest in developed economies, and the advanced knowledge of developed economies then spill back into emerging economies. RKS effects are generally more prevalent in emerging economies than developed economies in that emerging economies are more active in OFDI to seek strategic assets and technologies than developed economies [51-53]. Kogut and Chang [54] showed that Japan's overseas FDI is concentrated in the United States, since R\&D activities and outcomes of US companies can be shared, and the reverse technology spillovers of OFDI promote Japan's technological progress. Potterie and Lichtenberg [14] found that countries such as Japan, Germany, and France have benefitted from the United States' R\&D capital stock through outward investment. Herzer $[55,56]$ found that the RKS brought by OFDI promoted domestic total factor productivity (TFP) and economic growth. Masso and Vahter's research [57] confirms that Estonia obtained foreign advanced technology through OFDI, which has further promoted the country's technological progress. Driffield et al. [20] conclude that OFDI positively affected the TFP of the UK due to RKS at the industry level. Damijan et al. [58] and Temouri et al. [21] used firm-level data from Slovenia and Germany to conclude that RKS induced by OFDI promotes the growth of domestic TFP. The studies mentioned above show that OFDI induces positive RKS effects.

However, some studies find that not all cases can produce consistent and positive RKS effects [59,60]. Bitzer and Gorg [61] concluded that, for an aggregate of 17 OECD countries, OFDI had a negative effect on domestic TFP. Djankov and Hoekman [62] found these adverse effects for the Czech Republic. Jie [63] used data concerning China's OFDI to 14 countries from 1985-2006 and found that OFDI-induced RKS had no significant impact on TFP. Mingxia [64] also found that the effects of OFDI on home countries' technological progress are not apparent based on Chinese data from 1987 to 2008. Through these studies, we find that the empirical analysis with negative results is more concentrated in developing and emerging countries. Several reasons explain the adverse effects of OFDI-induced RKS. First, low-income countries suffering from capital shortages are even less equipped to innovate than high-income countries [65]. Second, OFDI could crowd out other economic activities in the investment home country, such as production and operations activities [66]. 
A decrease in economic activities causes a decreased demand for labor, resulting in a rising unemployment rate. Third, OFDI-induced RKS may lead domestic enterprises to rely excessively on foreign advanced technologies, causing them to lack the necessity and motivation to perform their research and thus reducing their innovation activities.

In this regard, the heterogeneity of the host country is also considered a reason for the different effects of OFDI-induced RKS $[13,15,48,50,67]$. That is mainly because the first phase of RKS—acquiring and absorbing unique knowledge assets-occurs in the host country, and the knowledge and technology that can be learned from the host country are more or less influenced by the local R\&D situation [68]. The world's R\&D innovative activities are highly concentrated in developed economies, while emerging and developing economies have limited innovation capacity and a lack of investment in cutting-edge technologies [15]. Therefore, investing in developed economies will create more opportunities to access cutting-edge technologies, and the effects of RKS are more likely to be effective [69]. Potterie and Lichtenberg [14] suggested that TFP is increased due to RKS in cases of OFDI in developed economies where R\&D is concentrated. Li et al. [70] found that RKS are more significant in emerging economies that invest in developed OECD countries rather than in other countries.

Previous studies in the literature show that emerging economies make outbound investments to acquire advanced knowledge and technologies and then influence domestic innovation through RKS effects. Such processes and their subsequent impact may vary depending on the heterogeneity of the host country.

\section{Research Methods}

This paper examines how OFDI-induced RKS affects home countries' sustainable development by using a panel dataset covering 30 Chinese Mainland provinces from 2003-2016. First of all, this study adopts a simultaneous equation model to resolve the possible endogenous problem. This study argues that OFDI-induced RKS influences innovation and sustainable development. However, innovation and sustainable development in an economic system can also affect the region's outward investment activities. Regions with high levels of development are more likely to have the capacity and opportunities to make outbound investments and conduct innovative activities [71]. OFDI, innovation, and sustainable development are endogenous with a dynamic and interactive relationship, which should be addressed in the empirical analysis. In this regard, OFDI-induced RKS, innovation, and sustainable development are set as the main endogenous variables in the model. To explore the heterogeneity of host countries, RKSs are divided according to the destination of OFDI into those from developed economies and those from emerging economies. In addition to these four endogenous variables, FDI-induced KS is also set as an endogenous variable, which has been studied and confirmed by many scholars [53,72-74]. The effect mechanism of KS is similar to RKS, but not as the focus of this study, only as a control item consideration. The completed simultaneous equation model consists of five endogenous variables and five corresponding equations:

$$
\begin{aligned}
& S D_{i t}=\alpha_{0}+\alpha_{1} S D_{i t-1}+\alpha_{2} I N N_{i t}+\alpha_{3} R K S \_e d_{i t}+\alpha_{4} R K S \_i n g i t+\alpha_{5} K S_{i t}+\omega_{i t} \\
& I N N_{i t}=\beta_{0}+\beta_{1} I N N_{i t-1}+\beta_{2} R K S \_e d_{i t}+\beta_{3} R K S \_i n g i t+\beta_{4} K S_{i t}+\beta_{5} R D_{-} \exp _{i t}+\beta_{6} R D_{-} \text {per } r_{i t}+\varphi_{i t} \\
& R K S \_e d_{i t}=\gamma_{0}+\gamma_{1} R K S_{-} e d_{i t-1}+\gamma_{2} G R P_{i t}+\gamma_{3} F A_{-} I N V_{i t}+\gamma_{4} \text { Trade }_{i t}+\gamma_{5} E M P_{i t}+\gamma_{6} I N D_{i t}+\tau_{i t} \\
& \text { RKS_ing } i t=\theta_{0}+\theta_{1} R K S \_i n g i t-1+\theta_{2} G R P_{i t}+\theta_{3} F A_{-} I N V_{i t}+\theta_{4} \operatorname{Trade}_{i t}+\theta_{5} E M P_{i t}+\theta_{6} I N D_{i t}+\sigma_{i t} \\
& K S_{i t}=\rho_{0}+\rho_{1} K S_{i t-1}+\rho_{2} G R P_{i t}+\rho_{3} F A_{-} I N V_{i t}+\rho_{4} \text { Trade }_{i t}+\rho_{5} E M P_{i t}+\rho_{6} I N D_{i t}+\pi_{i t}
\end{aligned}
$$

where $S D_{i t}$ denotes the sustainable development level of region $i$ in year $t$; INN denotes the innovation performance of region $i$ in year $t ; R K S \_e d_{i t}$ denotes OFDI-induced RKS from developed economies of region $i$ in year $t$; RKS_ing $i t$ denotes OFDI-induced RKS from emerging economies of region $i$ in year $t ; K S_{i t}$ denotes FDI-induced $K S$ of region $i$ in year $t$; $R D_{-} \exp _{i t}$ denotes the R\&D expenditure intensity of region $i$ in year $t ; R D_{-}$per $_{i t}$ denotes the R\&D personnel of region $i$ in year $t-1 ; G R P_{i t}$ denotes the gross regional product of region 
$i$ in year $\mathrm{t} ; F A_{-} I N V_{i t}$ denotes the total regional investment in fixed assets of region $i$ in year $t$; Trade $_{i t}$ denotes the amount of trade of region $i$ in year $t ; E M P_{i t}$ denotes the number of employees of region $i$ in year $t ; I N D_{i t}$ denotes the proportion of tertiary industry of region $i$ in year $t ; \omega_{i t}, \varphi_{i t}, \tau_{i t}, \sigma_{i t}$, and $\pi_{i t}$ denote the stochastic disturbance form.

To further measure the effects of OFDI-induced RKS on sustainable development, the direct effect, indirect effect, and total effect are calculated using the following mathematical formulas:

Formula (1): Total effect of OFDI-induced RKS from developed economies:

$$
\begin{gathered}
\left.\frac{\partial S D}{\partial R K S_{-} e d}=\alpha_{2} \cdot \frac{\partial I N N}{\partial R K S_{-} e d}(\text { Indirect Effect })+\alpha_{3} \text { (Direct Effect }\right) \\
=\alpha_{2} \cdot \beta_{2}+\alpha_{3}
\end{gathered}
$$

Formula (2): Total effect of OFDI-induced RKS from emerging economies:

$$
\begin{gathered}
\left.\frac{\partial S D_{D} i n g}{\partial R K S_{-}}=\alpha_{2} \cdot \frac{\partial I N N}{\partial R K S_{-} i n g} \text { (Indirect Effect }\right)+\alpha_{4} \text { (Direct Effect) } \\
=\alpha_{2} \cdot \beta_{3}+\alpha_{4}
\end{gathered}
$$

In addition to the composite sustainable development $(S D)$, three dimensions of sustainable development were analyzed in Equation (1): economic development (SD_Economic), social development (SD_Social), and environment development (SD_Environment). The above-listed empirical simultaneous equation model (Equations (1)-(5)) is estimated using the three-stage least squares (3SLS) method [75], which estimates the instrumental variables by considering the covariance across equation disturbances [76].

\section{Variable Specification}

\subsection{Sustainable Development Indicator}

The operationalization of sustainable development has been challenging because sustainable development involves a complex and multidimensional phenomenon, such that the construct cannot be measured by a single traditional economic or environmental indicator $[77,78]$. Based on the TBL $[79,80]$, this study operationalizes a sustainable development indicator system with three levels (see Table 1). The first-level indicator is the composite sustainable development indicator that reflects the comprehensive regional level. The second level includes three indicators for the three dimensions-economic, social, and environmental - that are the general dimensions of sustainable development. The third level involves 15 indicators; five are attributed to economic development, four to social development, and six to environmental development. These third-level indexes are classified as positive and negative based on the direction in which they affect the second level. These indicators are direct and indirect outcomes of institutional influence. For example, the wastewater treatment rate is the outcome of ecological policy and the stringency level of regulation, which is conceptually interpreted as contributing to institutional quality.

The data from the third-level indicators are collected and then calculated to obtain the upper-level indicators. To perform this calculation, the entropy evaluation method is used; this method determines the weight of the index according to the information provided by the observed values of various indicators. 
Table 1. Sustainable development indicator system.

\begin{tabular}{|c|c|c|c|c|c|}
\hline First level & Second Level & & Third Level $(j)$ & Units & Positive/Negative \\
\hline \multirow{15}{*}{$\begin{array}{l}\text { Composite } \\
\text { Sustainable } \\
\text { Development } \\
\quad(S D)\end{array}$} & \multirow{5}{*}{$\begin{array}{c}\text { Economic } \\
\text { Development } \\
\left(S D \_E c o n o m i c\right)\end{array}$} & 1 & $\begin{array}{c}\text { Per capita gross regional } \\
\text { product }(\mathrm{GRP})\end{array}$ & RMB yuan & Positive \\
\hline & & 2 & $\begin{array}{l}\text { The proportion of secondary } \\
\text { industry and tertiary industry } \\
\text { in the GRP }\end{array}$ & $\%$ & Positive \\
\hline & & 3 & Total investment in fixed assets & $\begin{array}{l}\text { Hundred million } \\
\text { RMB yuan }\end{array}$ & Positive \\
\hline & & 4 & Number of employees & 10,000 people & Positive \\
\hline & & 5 & Per capita value of trade & US Dollars & Positive \\
\hline & \multirow{4}{*}{$\begin{array}{l}\text { Social } \\
\text { Development } \\
\left(S D \_ \text {Social }\right)\end{array}$} & 6 & Per capita disposable income & RMB Yuan & Positive \\
\hline & & 7 & Per capita area of paved roads & Square meter & Positive \\
\hline & & 8 & $\begin{array}{l}\text { Per capita general public } \\
\text { expenditure for education }\end{array}$ & RMB yuan & Positive \\
\hline & & 9 & $\begin{array}{l}\text { Per capita postal and } \\
\text { telecommunications traffic }\end{array}$ & RMB yuan & Positive \\
\hline & \multirow{6}{*}{$\begin{array}{c}\text { Environmental } \\
\text { Development } \\
\left(S D \_E n v i r o n m e n t\right)\end{array}$} & 10 & Wastewater treatment rate & $\%$ & Positive \\
\hline & & 11 & $\begin{array}{l}\text { Comprehensive utilization rate } \\
\text { of industrial solid waste }\end{array}$ & $\%$ & Positive \\
\hline & & 12 & $\begin{array}{c}\text { Green covered area as \% of } \\
\text { completed area }\end{array}$ & $\%$ & Positive \\
\hline & & 13 & Industrial waste gas emissions & $\begin{array}{l}\text { Billion standard } \\
\text { cubic meters }\end{array}$ & Negative \\
\hline & & 14 & Total wastewater discharged & $10,000 \mathrm{t}$ & Negative \\
\hline & & 15 & $\begin{array}{l}\text { Industrial solid wastes } \\
\text { produced }\end{array}$ & $10,000 \mathrm{t}$ & Negative \\
\hline
\end{tabular}

Note: Dates are drawn from China Statistical Yearbook (2004-2017).

\subsection{OFDI-Induced RKS}

Potterie and Lichtenberg [14] investigated how foreign direct investments spill technological knowledge across borders; their study laid the foundation for calculating international KS (e.g., $[13,18,81,82])$. Based on their research, the present study uses the R\&D capital stock of the host country to measure the innovation level of that host country and uses the proportion of outward investment in the host country's domestic fixed investment as the OFDI weighting value. The specific calculation formula for OFDI-induced RKS $\left(R K S_{j t}\right)$ is as follows:

$$
R K S_{j t}=\frac{O F D I \_c_{j t}}{k_{j t}} S_{j t}^{d}
$$

where OFDI_ $c_{j t}$ is the outflow of the home-country FDI to country $j$ in year $t ; k_{j t}$ is the gross fixed capital formation (formerly gross domestic fixed investment) of country $j$ in year $t ; \frac{O F D I_{-} c_{j t}}{k_{j t}}$ represents the proportion of the investment home country's investment in the domestic fixed investment of the host country; $S_{j t}^{d}$ is the R\&D capital stock of country $j$ in year $t$, representing the technology development level of the host country; $R K S_{j t}$ represents the amount of R\&D capital (knowledge stock) that the investment home country can obtain from the host country through OFDI from country $j$ in year $t$. This study regards $R K S_{j t}$ as the amount of RKS the investment home country could gain through OFDI. Because of 
statistical limitations, R\&D capital stock is not directly available. The perpetual inventory method, a common method for calculating stock variable, is used as follows:

$$
S_{j t}^{d}=(1-\delta) S_{j(t-1)}^{d}+R \& D_{j t}
$$

where $S_{j t}^{d}$ is the R\&D capital stock of country $j$ in year $t ; \delta$ is the depreciation rate, which takes the value of $5 \%$ [83]; $R \& D_{j t}$ is the R\&D capital input of country $j$ in year $t$. Using 2003 as the base year, the R\&D capital stock of the base year is calculated using the perpetual inventory method:

$$
S_{j, 2003}=\frac{R \& D_{j, 2003}}{\delta+g_{j}}
$$

where $R \& D_{j, 2003}$ is the $R \& D$ capital input of country $j$ in 2003 , and $g_{j}$ is the average annual growth of R\&D capital input over 14 years (from 2003-2016) of country $j$.

The National Bureau of Statistics does not publish provincial OFDI data for specific host countries. Therefore, this study used the proportion of provincial OFDI in Chinese Mainland's total OFDI amount to calculate province-level RKS:

$$
R K S_{i j t}=\frac{O F D I \_p_{i t}}{\sum_{i=1}^{30} \text { OFDI_p } p_{i t}} \times R K S_{j t}
$$

where $R K S_{i j t}$ represents Chinese province I gains of OFDI-induced RKS from country $j$ in year $t$; OFDI_p $p_{i t}$ represents the flow of Chinese province $i$ 's OFDI in year $t ; R K S_{j t}$ is the total amount of OFDI-induced RKS of 30 Chinese Mainland provinces from country $j$ in year $t$.

FDI-induced KS (KS) was calculated using the above method by replacing the outward foreign investment in the formula with inward foreign investment. To explore the heterogeneity of the host countries' investments, the destination of OFDI is divided into two groups: developed economies and emerging economies. The $R K S_{i j t}$ for each group was summed to get RKS_ed $d_{i t}$ and RKS_ing $g_{i t}$ :

$$
\begin{aligned}
& R K S \_e d_{i t}=\sum_{j} R K S_{i j t}, j \in \text { Developed Economies Group } \\
& R K S \_i n g_{i t}=\sum_{j} R K S_{i j t}, j \in \text { Emerging Economies Group }
\end{aligned}
$$

This study selects 20 economies as samples of investment host countries (10 from developed economies and 10 from emerging economies, see Table 2). The reasons for choosing these economies are as follows. (1) Given the level of technology and innovation, the Chinese Mainland is taken as the standard. Chinese Mainland ranked 17th on the Global Innovation Index 2018, so developed economies ranked ahead of Chinese Mainland and were on the UN list of developed economies. Other economies are defined as emerging economies. (2) Considering the Chinese Mainland's investment situation in these countries, the selected economies are the main destination of outward direct investment. Chinese Mainland's total investment in these 20 economies was $\$ 1507.61$ billion, comprising $76.86 \%$ of the sum of Chinese OFDI in 2016.

Table 2. List of investment host countries.

\begin{tabular}{cc}
\hline Developed Economies & Emerging Economies \\
\hline Netherlands; Sweden; United Kingdom; & Thailand; Russian Federation; Mongolia; South \\
Singapore; United States; Germany; Korea, & Africa; Brazil; India; Philippines; Malaysia; \\
Rep; Japan; Chinese Hong Kong; France & Kazakhstan; Ukraine \\
\hline
\end{tabular}




\subsection{Innovation Performance}

This study uses the number of patent grants per GRP as a proxy for innovation performance. Using patent statistics to measure the level of regional innovation performance has certain advantages [84,85]. First, patents are the technological innovation outputs obtained through innovation activities; this condenses the input and experience in the $R \& D$ innovation process and can adequately reflect the level of regional technological innovation performance. Second, patents are widely accepted in the market and can be used to evaluate the value of innovation. Moreover, the patent data statistics of each region are relatively standardized and uniform, making them convenient to obtain and compare.

This paper takes Chinese Mainland provinces as the unit of analysis. A balanced panel dataset involving 30 provinces over the period 2003 to 2016 is employed in this paper. The Tibet municipality, with a large number of missing data, was excluded from the sample. Inevitably, there are some missing values in the official database. In order to ensure data integrity in the empirical analysis, this paper adopts the average growth rate method to complete the missing values. To avoid the inconsistency of variable units and large heteroscedasticity of data affecting the empirical analysis results, the data is transformed to logarithmic. Table 3 lists a description of the variables. The descriptive statistics of the variables are shown in Table 4.

Table 3. Description of variables.

\begin{tabular}{|c|c|c|c|c|}
\hline Type & & Variable & Proxy & Measurement (Units) \\
\hline \multirow{8}{*}{ Endogenous Variables } & \multirow{4}{*}{1} & SD & Sustainable Development Indicator & \multirow{4}{*}{ Refer to Section 4.1} \\
\hline & & SD_Economic & Economic Development Indicator & \\
\hline & & SD_Social & Social Development Indicator & \\
\hline & & SD_Environment & Environment Development Indicator & \\
\hline & 2 & INN & Innovation Performance & $\begin{array}{l}\text { Number of patent grants/GRP } \\
\text { (unit/RMB million yuan) }\end{array}$ \\
\hline & 3 & RKS_ed & $\begin{array}{l}\text { OFDI-Induced RKS from Developed } \\
\text { Economies }\end{array}$ & \multirow{2}{*}{$\begin{array}{c}\text { RKS/GRP } \\
(\% \text {; refer to Section 4.2) }\end{array}$} \\
\hline & 4 & RKS_ing & $\begin{array}{l}\text { OFDI-Induced RKS from Emerging } \\
\text { Economies }\end{array}$ & \\
\hline & 5 & KS & FDI-Induced KS & $\begin{array}{c}\text { KS/GRP } \\
(\% \text {; refer to Section } 4.2)\end{array}$ \\
\hline \multirow{7}{*}{ Exogenous Variables } & 5 & RD_exp & R\&D Expenditure Intensity & R\&D expenditure/GRP (\%) \\
\hline & 6 & RD_per & R\&D Personnel & $\begin{array}{l}\text { Number of R\&D personnel per } \\
\text { million people (people) }\end{array}$ \\
\hline & 7 & GRP & GRP & Per capital GRP (RMB yuan) \\
\hline & 8 & Trade & Trade Intensity & Trade/GRP (\%) \\
\hline & 9 & FA_INV & Total Investment in Fixed Assets & $\begin{array}{l}\text { Total investment in fixed } \\
\text { assets /GRP (\%) }\end{array}$ \\
\hline & 10 & EMP & Employees & $\begin{array}{c}\text { Number of employees (million } \\
\text { people) }\end{array}$ \\
\hline & 11 & IND & Industrial Structure & $\begin{array}{l}\text { Output value of tertiary } \\
\text { industry/output value of } \\
\text { secondary industry (\%) }\end{array}$ \\
\hline
\end{tabular}

Note: Dates are drawn from the China Statistical Yearbook (2004-2017), Statistical Bulletin of China's Outward Direct Investment (2004-2017), China Statistical Yearbook on Science and Technology (2004-2017), and World Bank Database. 
Table 4. Descriptive statistics of variables.

\begin{tabular}{ccccc}
\hline Variable & Mean & SD & Min & Max \\
\hline SD & 0.310 & 0.158 & 0.08 & 0.83 \\
SD_Economic & 0.242 & 0.189 & 0.04 & 0.79 \\
SD_Social & 0.266 & 0.194 & 0.03 & 0.95 \\
SD_Environment & 0.508 & 0.136 & 0.14 & 0.83 \\
INN & 0.011 & 0.009 & 0.001 & 0.055 \\
RKS_ed & 0.170 & 0.261 & 0 & 2.408 \\
RKS_ing & 0.008 & 0.015 & 0 & 0.178 \\
KS & 0.583 & 0.818 & 0.039 & 6.449 \\
RD_exp & 0.014 & 0.011 & 0.002 & 0.074 \\
RD_per & 3497 & 4025 & 289 & 21,273 \\
GRP & 33,448 & 23,094 & 3603 & 118,198 \\
Trade & 0.330 & 0.405 & 0.032 & 1.842 \\
FA_INV & 0.645 & 0.227 & 0.240 & 1.371 \\
EMP & 25.553 & 16.970 & 2.9 & 67.26 \\
IND & 0.944 & 0.493 & 0.494 & 4.165 \\
\hline
\end{tabular}

\section{Empirical Findings}

The completed empirical results of the simultaneous equation model are shown in Table 5. Composite sustainable development (SD), economic development (SD_Economic), social development (SD_Social), and environmental development (SD_Environment) were respectively analyzed as the endogenous variable of Equation (1).

According to Table 5, the direct, indirect, and total effects of OFDI-induced RKS on composite sustainable development and on the three dimensions of sustainable development were calculated. The results are shown in Table 6.

According to the results, a one-point increase in OFDI-induced RKS from developed economies (RKS_ed) led to a direct decrease in composite sustainable development by 0.072 points, a direct decrease in social development by 0.114 points, a direct decrease in environmental development by 0.185 points, and an increase in RKS_ed by one point. This increase in RKS_ed improved innovation performance and, therefore, indirectly led to an increase in composite sustainable development by 0.11 points and an increase in social development by 0.018 points.

The total effects of RKS from developed economies equaled the sum of the direct and indirect effects. An increase in RKS_ed by one point led to a decrease in the composite sustainable development by 0.061 points, a decrease in social development by 0.096 points, and a decrease in environmental development by 0.185 points. OFDI-induced RKSs from developed economies had no significant effect on economic development, either directly or indirectly, and they did not affect environmental development through innovation.

The positive indirect effects of OFDI-induced RKS from developed economies on composite sustainable development revealed that outward investing in developed economies brings advanced technology back to the investment home country and promotes innovation performance, thus contributing to sustainable development. This result was partly consistent with previous studies that found positive effects of RKS on home countries' technological processes (e.g., [56,57]). However, from 2003 to 2016, the direct adverse effects of RKS outweighed the positive indirect effects from developed economies and eventually impeded sustainable development, especially social and environmental development.

According to previous studies, several reasons explain the insignificant or even negative effects. The first is the substitution relationship between outbound and domestic investment $[86,87]$; outward investment in developed economies may reduce the domestic investment that would be used to promote local social and environmental development. Second, outbound investments may transfer domestic production and employment activities to foreign countries [66], thereby reducing the labor's income and raising the unemployment rate, both of which are harmful to social development. Third, the significantly positive effects of RKS require prerequisites. At the least, there must be enough 
economic activity within the region to participate in the process of RKS [66]. Furthermore, specific regional absorptive capacities are necessary to understand and transfer external knowledge [84,88,89]. From 2003 to 2016, the quantity and quality of Chinese companies involved in outbound investment activities were not sufficient to produce positive RKS effects on sustainable development.

Table 5. Empirical results of the simultaneous equation model.

\begin{tabular}{|c|c|c|c|c|c|}
\hline & SD & SD_Economic & & SD_Social & SD_Environment \\
\hline \multicolumn{6}{|c|}{ Equation (1): SD } \\
\hline SD_lag & $\begin{array}{c}0.582^{* * *} \\
(11.84)\end{array}$ & $\begin{array}{c}0.831^{* * *} \\
(23.40)\end{array}$ & & $\begin{array}{c}0.425^{* * *} \\
(8.79)\end{array}$ & $\begin{array}{c}0.588^{* * *} \\
(12.43)\end{array}$ \\
\hline INN & $\begin{array}{c}0.944^{* * *} \\
(2.77)\end{array}$ & $\begin{array}{l}0.182 \\
(0.86)\end{array}$ & & $\begin{array}{c}1.818^{* * *} \\
(2.79)\end{array}$ & $\begin{array}{l}0.676 \\
(0.62)\end{array}$ \\
\hline RKS_ed & $\begin{array}{c}-0.072^{* *} \\
(-2.29)\end{array}$ & $\begin{array}{l}-0.016 \\
(-0.85)\end{array}$ & & $\begin{array}{c}-0.114 \\
(-1.83)\end{array}$ & $\begin{array}{c}-0.185 * \\
(-1.78)\end{array}$ \\
\hline RKS_ing & $\begin{array}{l}1.021^{*} \\
(1.66)\end{array}$ & $\begin{array}{c}-0.924^{* * *} \\
(-2.65)\end{array}$ & & $\begin{array}{c}3.797 * * * \\
(3.24)\end{array}$ & $\begin{array}{l}2.667 \\
(1.33)\end{array}$ \\
\hline KS & $\begin{array}{c}-0.010^{* *} \\
(-1.99)\end{array}$ & $\begin{array}{c}-0.007^{* *} \\
(-2.68)\end{array}$ & & $\begin{array}{l}-0.003 \\
(-0.36)\end{array}$ & $\begin{array}{l}-0.024 \\
(-1.46)\end{array}$ \\
\hline _Cons & $\begin{array}{c}0.131^{* * *} \\
(8.24)\end{array}$ & $\begin{array}{c}0.057^{* * * *} \\
(6.45)\end{array}$ & & $\begin{array}{c}0.126^{* * *} \\
(7.30)\end{array}$ & $\begin{array}{c}0.227^{* * * *} \\
(7.79)\end{array}$ \\
\hline \multicolumn{6}{|c|}{ Equation (2): INN } \\
\hline INN_lag & $\begin{array}{c}0.772 * * * \\
(25.63)\end{array}$ & $\begin{array}{c}0.771^{* * *} \\
(26.11)\end{array}$ & & $\begin{array}{c}0.778^{* * *} \\
(25.93)\end{array}$ & $\begin{array}{c}0.775^{* * *} \\
(26.15)\end{array}$ \\
\hline RKS_ed & $\begin{array}{c}0.012 * * * \\
(3.73)\end{array}$ & $\begin{array}{c}0.007^{* *} \\
(1.99)\end{array}$ & & $\begin{array}{c}0.010^{* * *} \\
(2.64)\end{array}$ & $\begin{array}{c}0.008^{* * *} \\
(2.72)\end{array}$ \\
\hline RKS_ing & $\begin{array}{c}-0.278^{* * *} \\
(-4.87)\end{array}$ & $\begin{array}{c}-0.158^{* *} \\
(-2.36)\end{array}$ & & $\begin{array}{c}-0.245^{* * *} \\
(-3.43)\end{array}$ & $\begin{array}{c}-0.175^{* * *} \\
(-3.17)\end{array}$ \\
\hline KS & $\begin{array}{l}-0.0004 \\
(-0.86)\end{array}$ & $\begin{array}{l}-0.001 \\
(-1.25)\end{array}$ & & $\begin{array}{l}-0.001 \\
(-1.32)\end{array}$ & $\begin{array}{l}-0.001 \\
(-1.24)\end{array}$ \\
\hline RD_exp & $\begin{array}{l}0.006 \\
(0.08)\end{array}$ & $\begin{array}{l}0.019 \\
(0.25)\end{array}$ & & $\begin{array}{l}0.040 \\
(0.51)\end{array}$ & $\begin{array}{l}0.025 \\
(0.35)\end{array}$ \\
\hline RD_per & $\begin{array}{c}0.001 \text { ** } \\
(2.01)\end{array}$ & $\begin{array}{c}0.002^{* * *} \\
(2.65)\end{array}$ & & $\begin{array}{l}0.001 \\
(1.38)\end{array}$ & $\begin{array}{c}0.001 * * \\
(2.26)\end{array}$ \\
\hline _Cons & $\begin{array}{l}-0.007 \\
(-1.48)\end{array}$ & $\begin{array}{c}-0.010 * * \\
(-2.17)\end{array}$ & & $\begin{array}{l}-0.004 \\
(-0.88)\end{array}$ & $\begin{array}{c}-0.008 * \\
(-1.79)\end{array}$ \\
\hline Equation (3): RKS_ed & SD & Equation (4): RKS_ing & SD & Equation (5): KS & SD \\
\hline RKS_ed_lag & $\begin{array}{c}0.139 * * * \\
(3.30)\end{array}$ & RKS_ing_lag & $\begin{array}{c}0.0295 \\
(0.71)\end{array}$ & KS_lag & $\begin{array}{c}0.610^{* * *} \\
(17.01)\end{array}$ \\
\hline GRP & $\begin{array}{l}0.052 \\
(1.31)\end{array}$ & GRP & $\begin{array}{l}0.001 \\
(0.32)\end{array}$ & GRP & $\begin{array}{l}-0.079 \\
(-1.19)\end{array}$ \\
\hline FA_INV & $\begin{array}{c}-0.188^{* *} \\
(-1.97)\end{array}$ & FA_INV & $\begin{array}{l}-0.008 \\
(-1.24)\end{array}$ & FA_INV & $\begin{array}{l}0.069 \\
(0.43)\end{array}$ \\
\hline Trade & $\begin{array}{c}-0.237^{* * *} \\
(-2.63)\end{array}$ & Trade & $\begin{array}{l}-0.012 * \\
(-1.87)\end{array}$ & Trade & $\begin{array}{l}0.151 \\
(0.97)\end{array}$ \\
\hline EMP & $\begin{array}{c}0.643 * * * \\
(3.30)\end{array}$ & EMP & $\begin{array}{l}0.016 \\
(1.24)\end{array}$ & EMP & $\begin{array}{l}-0.433 \\
(-1.31)\end{array}$ \\
\hline IND & $\begin{array}{c}0.152^{* * *} \\
(2.80)\end{array}$ & IND & $\begin{array}{l}0.004 \\
(1.02)\end{array}$ & IND & $\begin{array}{l}-0.072 \\
(-0.81)\end{array}$ \\
\hline _Cons & $\begin{array}{c}-2.270^{* * *} \\
(-4.34)\end{array}$ & _Cons & $\begin{array}{l}-0.045 \\
(-1.28)\end{array}$ & _Cons & $\begin{array}{l}2.251 \\
(2.37)\end{array}$ \\
\hline
\end{tabular}

Note: T-values are shown in parentheses; ${ }^{*}, * *$ and ${ }^{* * *}$ denote statistical significance at $1 \%, 5 \%$, and $10 \%$, respectively. The results of Equations (3)-(5) are based on the composite sustainable development. 
Table 6. Effects of OFDI-induced RKS on sustainable development.

\begin{tabular}{|c|c|c|c|c|}
\hline & SD & SD_Economic & SD_Social & SD_Environment \\
\hline \multicolumn{5}{|c|}{ The Effect of OFDI-Induced RKS from Developed Economies on Sustainable Development } \\
\hline Direct Effect & -0.072 & - & -0.114 & -0.185 \\
\hline $\begin{array}{l}\text { Indirect Effect } \\
\text { (through } \\
\text { innovation) }\end{array}$ & $\begin{array}{l}0.944 \times 0.012 \\
\quad=0.011\end{array}$ & - & $\begin{array}{l}1.818 \times 0.01 \\
=0.018\end{array}$ & - \\
\hline Total Effect & -0.061 & - & -0.096 & -0.185 \\
\hline \multicolumn{5}{|c|}{ The Effect of OFDI-Induced RKS from Emerging economies on Sustainable Development } \\
\hline Direct Effect & 1.021 & -0.924 & 3.797 & - \\
\hline $\begin{array}{l}\text { Indirect Effect } \\
\text { (through } \\
\text { innovation) }\end{array}$ & $\begin{array}{c}0.944 \times-0.278 \\
=-0.262\end{array}$ & - & $\begin{array}{c}1.818 \times-0.245 \\
=-0.445\end{array}$ & - \\
\hline Total Effect & 0.759 & -0.924 & 3.352 & - \\
\hline
\end{tabular}

The bottom of Table 6 shows the results of OFDI-induced RKS from emerging economies (RKS_ing). An increase in RKS_ing by one point directly led to an increase in composite sustainable development by 1.021 points, a decrease in economic development by 0.0924 points, and an increase in social development by 3.797 points. An increase in RKS_ing by one point also indirectly led to a decrease of 0.262 points in composite sustainable development and 0.445 points in social development by impeding innovation. After combining the direct and indirect effects, the total effects suggested that an increase in RKS_ing by one point led to an increase in sustainable development by 0.759 points, a decrease in economic development by 0.924 points, and an increase in social development by 3.352 points. RKS_ing had no effects on environmental development and had no indirect effects on economic development through innovation.

In a similar vein of previous studies, emerging economies do not have the technological advantages and infrastructure necessary to facilitate KS [15]. Therefore, OFDI-induced RKS from emerging economies have little effect on home countries' innovation performance and may even hamper their innovation $[14,70]$. However, outward investment in emerging economies generally is a vertical investment in primary industries to access natural resources or labor and reduce production costs [90,91]. Furthermore, investment in emerging economies helps regions transfer and upgrade industries, creating a direct positive impact on sustainable development [92].

\section{Conclusions}

Globalization has enabled more and more enterprises from emerging economies to conduct investment activities around the world, and emerging economies no longer blindly pursue high-speed economic growth. Following developed economies, sustainable development has become a goal for emerging economies to achieve as well. However, the effects of overseas investment from emerging economies on their domestic sustainable development are unknown, and how OFDI-induced RKS promotes domestic innovation performance and then benefits sustainable development is still unclear. Another important aspect to note is the attributes and originality of sustainable development. Economic, social, and environmental dimensions are three pillars that comprise the comprehensive sustainable development. Each dimension has four to six indicators. "How these indicators are developed?" and "What kind of concept do the indicators contain?" are very important questions when discussing the influence of independent variables on the dependent variable. In our paper, institutional-quality-related sustainable development indicators are suggested.

To delve into the research question posed above, building on a panel dataset involving 30 provinces of the Chinese Mainland from 2003-2016, sustainable development indicators and OFDI-induced RKS were calculated. Given the simultaneity and endogeneity between 
variables, a simultaneous equation model was used as an empirical technique to test the complicated relationship between OFDI-induced RKS, domestic innovation performance, and sustainable development. The empirical results indicated that OFDI-induced RKSs from developed economies promoted domestic innovation; however, during the period from 2003 to 2016, an insufficient quantity and quality of Chinese enterprises existed to participate in the RKS process. Thus, OFDI-induced RKS from developed economies could not fully have a positive effect, which was not conducive to sustainable development. In comparison, investment in emerging economies promoted the sustainable development of the region; investment in emerging economies helps the investment region transfer and upgrade basic industries. Moreover, Chinese multinationals investing in countries along the "One Belt and One Road" route received policy support from both the domestic and host countries, such as tax breaks and investment subsidies; this provided more opportunities for innovation activities or regional construction activities and thus promoted sustainable development.

The findings of this paper offer several implications for implementation and policymaking regarding OFDI, innovation, and sustainable development. First, emerging economies should continue to encourage enterprises to invest overseas. OFDI-induced RKS can be a source of sustainable development. The knowledge gained from abroad promotes domestic innovation, which enables emerging economies to pursue the two opposing concepts of sustainability and development at the same time. Moreover, when more enterprises participate in the RKS process, it can be effective for sustainable development. Secondly, emerging economies should pay more attention to the environment and increase environment-related outbound investment so that RKS can play a role in environmentally sustainable development. Since environmental innovation requires long-term and intensive R\&D investment, not all firms are actively engaged in environmental innovation, which requires long-term and intensive R\&D investment. Strategic choices are made based on the situation of the company, including, but not limited to, the size of the company, the industry it belongs to, and the perception of the consumer environment in the market. In particular, large-scale R\&D failures can affect a firm's survival. Therefore, it is necessary to promote and support environmental innovation at the government level. Finally, despite the attractiveness of countries with advanced technology for investment, multinationals from emerging economies cannot ignore investment in less technologically advanced countries that can help upgrade domestic industries and achieve sustainable development.

The following limitations of this paper provide an avenue for future research. First, this paper only studies the role of outward FDI induced reverse knowledge spillover in foreign investment, while other channels or paths to achieve sustainable development have not been explored. In future studies, sustainable development can be further refined, for example, by focusing on environmental sustainable development or social sustainable development. In addition, the impact pathway between RKS and sustainable development needs to be further studied. Second, this study failed to subdivide OFDI, because related data were unavailable; the investment industry can be considered to divide OFDI into vertical investment and horizontal investment, and the form of investment can be used as a basis for dividing OFDI into M\&A and greenfield investment in future studies. Thirdly, a greater variety of emerging economies should be studied to enrich the understanding of the relationship between OFDI-induced RKS and sustainable development in emerging economies. Finally, this study has a limitation in that the theoretical discussion on sustainable development indicators based on institutional quality is insufficient. This part will be left for further study.

Author Contributions: Conceptualization: X.D. and Y.S.H.; formal analysis: X.D.; project administration: Y.S.H.; supervision: Y.S.H.; writing—original draft: X.D., C.Y. and Y.S.H.; writing—review and editing: C.Y. and Y.S.H. All authors have read and agreed to the published version of the manuscript.

Funding: This study received no external funding.

Institutional Review Board Statement: Not applicable. 
Informed Consent Statement: Not applicable.

Data Availability Statement: Publicly available datasets were analyzed in this study. These dates are drawn from the China Statistical Yearbook (2004-2017), Statistical Bulletin of China's Outward Direct Investment (2004-2017), China Statistical Yearbook on Science and Technology (2004-2017), and World Bank Database.

Acknowledgments: This work was supported by the Ministry of Education of the Republic of Korea and the National Research Foundation of Korea (NRF-2020S1A5A2A01044259).

Conflicts of Interest: The authors declare no conflict of interest.

\section{References}

1. United Nations (UN). Transforming Our World: The 2030 Agenda for Sustainable Development; United Nations: New York, NY, USA, 2015.

2. United Nations (UN). Report of the World Commission on Environment and Development: Our Common Future; United Nations: New York, NY, USA, 1987.

3. Johnstone, N.; Haščič, I.; Popp, D. Renewable Energy Policies and Technological Innovation: Evidence Based on Patent Counts. Environ. Resour. Econ. 2010, 45, 133-155. [CrossRef]

4. Lélé, S.M. Sustainable development: A critical review. World Dev. 1991, 19, 607-621. [CrossRef]

5. Silvestre, B.S. Sustainable supply chain management in emerging economies: Environmental turbulence, institutional voids and sustainability trajectories. Int. J. Prod. Econ. 2015, 167, 156-169. [CrossRef]

6. Silvestre, B.S.; Ţîrcă, D.M. Innovations for sustainable development: Moving toward a sustainable future. J. Clean. Prod. 2019, 208, 325-332. [CrossRef]

7. Kirchhoff, B.A.; Newbert, S.L.; Hasan, I.; Armington, C. The Influence of University R \& D Expenditures on New Business Formations and Employment Growth. Entrep. Theory Pract. 2007, 31, 543-559. [CrossRef]

8. OECD. OECD Science, Technology and Industry Outlook 2012; OECD Publishing: Paris, France, 2012; ISBN 9789264170391. [CrossRef]

9. Long, X.; Chen, Y.; Du, J.; Oh, K.; Han, I.; Yan, J. The effect of environmental innovation behavior on economic and environmental performance of 182 Chinese firms. J. Clean. Prod. 2017, 166, 1274-1282. [CrossRef]

10. Lemke, C.; Bastini, K. Embracing multiple perspectives of sustainable development in a composite measure: The Multilevel Sustainable Development Index. J. Clean. Prod. 2020, 246, 118884. [CrossRef]

11. Vollebergh, H.R.J.; Kemfert, C. The role of technological change for a sustainable development. Ecol. Econ. 2005, 54, 133-147. [CrossRef]

12. Vollenbroek, F.A. Sustainable development and the challenge of innovation. J. Clean. Prod. 2002, 10, 215-223. [CrossRef]

13. Li, J.; Strange, R.; Ning, L.; Sutherland, D. Outward foreign direct investment and domestic innovation performance: Evidence from China. Int. Bus. Rev. 2016, 25, 1010-1019. [CrossRef]

14. Potterie, B.V.P.D.L.; Lichtenberg, F. Does Foreign Direct Investment Transfer Technology Across Borders? Rev. Econ. Stat. 2001, 83, 490-497. [CrossRef]

15. Zhou, C.; Hong, J.; Wu, Y.; Marinova, D. Outward foreign direct investment and domestic innovation performance: Evidence from China. Technol. Anal. Strateg. Manag. 2019, 31, 81-95. [CrossRef]

16. Javorcik, B.S. Does Foreign Direct Investment Increase the Productivity of Domestic Firms? In Search of Spillovers Through Backward Linkages. Am. Econ. Rev. 2004, 94, 605-627. [CrossRef]

17. Coe, D.T.; Helpman, E. International R\&D spillovers. Eur. Econ. Rev. 1995, 39, 859-887. [CrossRef]

18. Seck, A. International technology diffusion and economic growth: Explaining the spillover benefits to developing countries. Struct. Chang. Econ. Dyn. 2012, 23, 437-451. [CrossRef]

19. Driffield, N.; Love, J.H. Foreign Direct Investment, Technology Sourcing and Reverse Spillovers. Manch. Sch. 2003, 71, 659-672. [CrossRef]

20. Driffield, N.; Love, J.H.; Taylor, K. Productivity and labour demand effects of inward and outward foreign direct investment on UK industry. Manch. Sch. 2009, 77, 171-203. [CrossRef]

21. Temouri, Y.; Driffield, N.L.; Higón, D.A. German outward FDI and firm performance. Appl. Econ. Q. 2010, 56, 31-50. [CrossRef]

22. Zhang, K.-M.; Wen, Z.-G. Review and challenges of policies of environmental protection and sustainable development in China. J. Environ. Manag. 2008, 88, 1249-1261. [CrossRef]

23. United Nations (UN). Report of the United Nations Conference on Environment and Development, Rio de Janeiro, 3-14 June 1992; United Nations: New York, NY, USA, 1993.

24. Rogers, M.; Ryan, R. The Triple Bottom Line for Sustainable Community Development. Local Environ. 2001, 6, 279-289. [CrossRef]

25. Giddings, B.; Hopwood, B.; O’Brien, G. Environment, economy and society: Fitting them together into sustainable development. Sustain. Dev. 2002, 10, 187-196. [CrossRef]

26. Spangenberg, J.H. Will the information society be sustainable? Towards criteria and indicators for a sustainable knowledge society. Int. J. Innov. Sustain. Dev. 2005, 1, 85-102. [CrossRef]

27. Goel, P. Triple Bottom Line Reporting: An Analytical Approach for Corporate Sustainability. J. Financ. Account. Manag. 2010, 1, $27-42$. 
28. Plessis, C.D. The mythology of sustainable development and its place in the developing world: A think piece. In Proceedings of the Strategies for Sustainable Built Environment Conference, CSIR, Pretoria, South Africa, 23-25 August 2000.

29. Barton, C. Aiming at the target: Achieving the objects of sustainable development in agency decision-making. Georget. Int. Environ. Law Rev. 2000, 13, 837.

30. Daly, H.E. Allocation, distribution, and scale: Towards an economics that is efficient, just, and sustainable. Ecol. Econ. 1992, 6, 185-193. [CrossRef]

31. Wackernagel, M.; Rees, W. Our Ecological Footprint: Reducing Human Impact on the Earth; New Society Publishers: Gabriola Island, BC, Canada, 1996; ISBN 086571312X.

32. Huisingh, D.; Tukker, A.; Lozano, R.; Quist, J. 'Knowledge Collaboration \& Learning for Sustainable Innovation': An introduction to this special volume. J. Clean. Prod. 2013, 48,1-2. [CrossRef]

33. Shrivastava, P.; Ivanaj, S.; Ivanaj, V. Strategic technological innovation for sustainable development. Int. J. Technol. Manag. 2016, 70, 76-107. [CrossRef]

34. Romer, P.M. Increasing Returns and Long-Run Growth. J. Political Econ. 1986, 94, 1002-1037. [CrossRef]

35. Romer, P.M. Endogenous Technological Change. J. Political Econ. 1990, 98, S71-S102. [CrossRef]

36. Lucas, R.E. On the mechanics of economic development. J. Monet. Econ. 1988, 22, 3-42. [CrossRef]

37. Akcali, B.Y.; Sismanoglu, E. Innovation and the Effect of Research and Development (R\&D) Expenditure on Growth in Some Developing and Developed Countries. Procedia Soc. Behav. Sci. 2015, 195, 768-775. [CrossRef]

38. Guloglu, B.; Tekin, R.B. A Panel Causality Analysis of the Relationship among Research and Development, Innovation, and Economic Growth in High-Income OECD Countries. Eurasian Econ. Rev. 2012, 2, 32-47.

39. Solow, R.M. The Economics of Resources or the Resources of Economics. In Classic Papers in Natural Resource Economics; Gopalakrishnan, C., Ed.; Palgrave Macmillan: London, UK, 2000; pp. 257-276. ISBN 978-0-230-52321-0. [CrossRef]

40. Yu, C.; Park, J.; Hwang, Y.S. How Do Anticipated and Self Regulations and Information Sourcing Openness Drive Firms to Implement Eco-Innovation? Evidence from Korean Manufacturing Firms. Int. J. Environ. Res. Public Health 2019, 16, 2678. [CrossRef] [PubMed]

41. Zhang, Y.-J.; Peng, Y.-L.; Ma, C.-Q.; Shen, B. Can environmental innovation facilitate carbon emissions reduction? Evidence from China. Energy Policy 2017, 100, 18-28. [CrossRef]

42. Lorente, D.B.; Álvarez-Herránz, A.; Torres, J.B. Innovation and Energy Substitution as Measures of Environmental Correction in OECD Countries. Estud. Econ. Appl. 2016, 34, 235-260.

43. Fernández, Y.F.; López, M.A.F.; Blanco, B.O. Innovation for sustainability: The impact of R\&D spending on $\mathrm{CO}_{2}$ emissions. J. Clean. Prod. 2018, 172, 3459-3467. [CrossRef]

44. Wang, M.; Zhao, X.; Gong, Q.; Ji, Z. Measurement of regional green economy sustainable development ability based on entropy weight-topsis-coupling coordination degree-A case study in Shandong Province, China. Sustainability 2019, 11, 280. [CrossRef]

45. Liu, Z.; Xin, L. Has China's Belt and Road Initiative promoted its green total factor productivity?-Evidence from primary provinces along the route. Policy 2019, 129, 360-369. [CrossRef]

46. Popp, D. The Role of Technological Change in Green Growth; The World Bank: Washington, DC, USA, 2012. [CrossRef]

47. Grossman, G.M.; Helpman, E. Innovation and Growth in the Global Economy; MIT Press: London, UK, $1991 ;$ ISBN 0262570971.

48. Li, M.; Li, D.; Lyles, M.; Liu, S. Chinese MNEs' Outward FDI and Home Country Productivity: The Moderating Effect of Technology Gap. Glob. Strategy J. 2016, 6, 289-308. [CrossRef]

49. Xia, J.; Ortiz, J.; Wang, H. Reverse technology spillover effects of outward FDI to PR China: A threshold regression analysis. Appl. Econ. Q. 2016, 62, 51-67. [CrossRef]

50. Zhou, Y.; Jiang, J.; Ye, B.; Hou, B. Green spillovers of outward foreign direct investment on home countries: Evidence from China's province-level data. J. Clean. Prod. 2019, 215, 829-844. [CrossRef]

51. Awate, S.; Larsen, M.M.; Mudambi, R. Accessing vs. sourcing knowledge: A comparative study of R\&D internationalization between emerging and advanced economy firms. J. Int. Bus. Stud. 2015, 46, 63-86. [CrossRef]

52. Child, J.; Rodrigues, S.B. The Internationalization of Chinese Firms: A Case for Theoretical Extension? Manag. Organ. Rev. 2005, 1,381-410. [CrossRef]

53. Dunning, J.H. Assessing the Costs and Benefits of Foreign Direct Investment: Some Theoretical Considerations. In Foreign Investment and Privatization in Eastern Europe; Artisien-Maksimenko, P., Rojec, M., Eds.; Palgrave Macmillan: London, UK, 1993; pp. 34-81. ISBN 978-1-349-22648-1. [CrossRef]

54. Kogut, B.; Chang, S.J. Technological Capabilities and Japanese Foreign Direct Investment in the United States. Rev. Econ. Stat. 1991, 73, 401-413. [CrossRef]

55. Herzer, D. Outward FDI and economic growth. J. Econ. Stud. 2010, 37, 476-494. [CrossRef]

56. Herzer, D. The long-run effect of outward FDI on domestic output in developing countries. Appl. Econ. Lett. 2011, 18, 1355-1358. [CrossRef]

57. Masso, J.; Vahter, P. Innovation and Firm Performance in the Services Sector in Estonia. In Innovation Systems in Small Catching-Up Economies: New Perspectives on Practice and Policy; Carayannis, E.G., Varblane, U., Roolaht, T., Eds.; Springer: New York, NY, USA, 2012; pp. 121-138. ISBN 978-1-4614-1548-0. [CrossRef]

58. Damijan, J.P.; Polanec, S.; Prašnikar, J. Outward FDI and Productivity: Micro-evidence from Slovenia. World Econ. 2007, 30, 135-155. [CrossRef] 
59. Holtbrügge, D.; Kreppel, H. Determinants of outward foreign direct investment from BRIC countries: An explorative study. Int. J. Emerg. Mark. 2012, 7, 4-30. [CrossRef]

60. Morck, R.; Yeung, B.; Zhao, M. Perspectives on China's outward foreign direct investment. J. Int. Bus. Stud. 2008, 39, 337-350. [CrossRef]

61. Bitzer, J.; Görg, H. Foreign Direct Investment, Competition and Industry Performance. World Econ. 2009, 32, 221-233. [CrossRef]

62. Djankov, S.; Hoekman, B. Foreign Investment and Productivity Growth in Czech Enterprises. World Bank Econ. Rev. 2000, 14, 49-64. [CrossRef]

63. Jie, B. The Effect of the Reverse Technology Spillover of Chinese Outward Direct Investment on TFP: An Empirical Analysis. World Econ. Study 2009, 8, 65-70.

64. Mingxia, L. Reverse Technology Spillovers of China's Outward FDI: Based on the Impact of Technological Gap. J. Zhongnan Univ. Econ. Law 2010, 3, 16-21+142.

65. Herzer, D.; Schrooten, M. Outward FDI and domestic investment in two industrialized countries. Econ. Lett. 2008, 99, 139-143. [CrossRef]

66. Knoerich, J. How does outward foreign direct investment contribute to economic development in less advanced home countries? Oxf. Dev. Stud. 2017, 45, 443-459. [CrossRef]

67. Lyles, M.; Li, D.; Yan, H. Chinese Outward Foreign Direct Investment Performance: The Role of Learning. Manag. Organ. Rev. 2014, 10, 411-437. [CrossRef]

68. Yao, Y. Study on reverse technological spillover from outward direct investment. In Proceedings of the 2016 International Conference on Advances in Management, Arts and Humanities Science (AMAHS 2016), Hong Kong, China, 10-11 December 2016; pp. 62-66.

69. Anderson, J.; Sutherland, D.; Severe, S. An event study of home and host country patent generation in Chinese MNEs undertaking strategic asset acquisitions in developed markets. Int. Bus. Rev. 2015, 24, 758-771. [CrossRef]

70. Li, L.; Liu, X.; Yuan, D.; Yu, M. Does outward FDI generate higher productivity for emerging economy MNE-Micro-level evidence from Chinese manufacturing firms. Int. Bus. Rev. 2017, 26, 839-854. [CrossRef]

71. Chen, C. Impact of China's outward foreign direct investment on its regional economic growth. China World Econ. 2018, 26, 1-21. [CrossRef]

72. Aitken, B.J.; Harrison, A.E. Do Domestic Firms Benefit from Direct Foreign Investment? Evidence from Venezuela. Am. Econ. Rev. 1999, 89, 605-618. [CrossRef]

73. Branstetter, L. Is foreign direct investment a channel of knowledge spillovers? Evidence from Japan's FDI in the United States. J. Int. Econ. 2006, 68, 325-344. [CrossRef]

74. Walz, U. Innovation, Foreign Direct Investment and Growth. Economica 1997, 64, 63-79. [CrossRef]

75. Zellner, A.; Theil, H. Three-Stage Least Squares: Simultaneous Estimation of Simultaneous Equations. Econometrica 1962, 30, 54-78. [CrossRef]

76. Greene, W.H. Econometric Analysis, 6th ed.; Pearson: London, UK, 2008; ISBN 9780135132456.

77. Grybaite, V.; Tvaronavičiene, M. Estimation of sustainable development: Germination on institutional level. J. Bus. Econ. Manag. 2008, 9, 327-334. [CrossRef]

78. Sun, H.; Mohsin, M.; Alharthi, M.; Abbas, Q. Measuring environmental sustainability performance of South Asia. J. Clean. Prod. 2020, 251, 119519. [CrossRef]

79. Elkington, J. Towards the Sustainable Corporation: Win-Win-Win Business Strategies for Sustainable Development. Calif. Manag. Rev. 1994, 36, 90-100. [CrossRef]

80. Elkington, J. Cannibals with Forks: The Triple Bottom Line of Twenty-First Century Business; Capstone: Oxford, UK, 1997; ISBN 190096127X.

81. Hong, J.; Zhou, C.; Wu, Y.; Wang, R.; Marinova, D. Technology Gap, Reverse Technology Spillover and Domestic Innovation Performance in Outward Foreign Direct Investment: Evidence from China. China World Econ. 2019, 27, 1-23. [CrossRef]

82. Jiao, J.; Jiang, G.; Yang, R. Impact of R\&D technology spillovers on carbon emissions between China's regions. Struct. Chang. Econ. Dyn. 2018, 47, 35-45. [CrossRef]

83. Coe, D.T.; Helpman, E.; Hoffmaister, A.W. International R\&D spillovers and institutions. Eur. Econ. Rev. 2009, 53, 723-741. [CrossRef]

84. Filippetti, A.; Frenz, M.; Ietto-Gillies, G. The impact of internationalization on innovation at countries' level: The role of absorptive capacity. Camb. J. Econ. 2017, 41, 413-439. [CrossRef]

85. Wang, C.C.; Lin, G.C.S. Emerging geography of technological innovation in China's ICT industry: Region, inter-firm linkages and innovative performance in a transitional economy. Asia Pac. Viewp. 2013, 54, 33-48. [CrossRef]

86. Tsung-Li, W.; Lin, H.-P.; Yang, C.-L. Causality on Outward Foreign Direct Investment and Domestic Investment In Newly Industrialized Asian Countries. Econ. Comput. Econ. Cybern. Stud. Res. 2017, 51, 267-280.

87. You, K.; Solomon, O.H. China's outward foreign direct investment and domestic investment: An industrial level analysis. China Econ. Rev. 2015, 34, 249-260. [CrossRef]

88. Liang, F.H. Does foreign direct investment improve the productivity of domestic firms? Technology spillovers, industry linkages, and firm capabilities. Res. Policy 2017, 46, 138-159. [CrossRef] 
89. Rojec, M.; Knell, M. Why is there a lack of evidence on knowledge spillovers from foreign direct investment? J. Econ. Surv. 2018, 32, 579-612. [CrossRef]

90. Alfaro, L. Gains from Foreign Direct Investment: Macro and Micro Approaches. World Bank Econ. Rev. 2016, 30, S2-S15. [CrossRef]

91. Markusen, J.R.; Venables, A.J.; Konan, D.E.; Zhang, K.H. A Unified Treatment of Horizontal Direct Investment, Vertical Direct Investment, and the Pattern of Trade in Goods and Services; National Bureau of Economic Research: Cambridge, MA, USA, 1996; pp. 898-2937.

92. Yang, Y.; Liu, C.-X. The Relationship between OFDI and Industrial Upgrading with the Background of One Belt and One Road. J. South. China Norm. Univ. Soc. Sci. Ed. 2015, 5, 93-101. 